る. いっぽう, 線維芽細胞型の髄膜腫の特徴は, 網状線 維や膠原線維の中に線維芽細胞様の線維が混入し, 紡鏵 形をした䯣膜上皮細胞がこれらの線維と一体化し，一見 して神経線維腫に類似の組織像を示すといわれている. これらの分類から考えて, 本症例は腫瘍塊の中心部が広 範囲にわたり硝子化を起こし，著明な石灰沈着がみられ たが，いわゆる渦紋状構造の中心部が硝子化を示すもの の石灰化まで進んだ組織像は認められなかったことから 判断して，髄膜上皮型の髄膜腫と診断された.

さて，この症例の発生原因については，不明なところ が多く, 推測の域を出ないが一応その経歴や解剖所見な どを考慮して，次のように推察される．この患犬は，生 後 4 才の時繁殖犬として米国から輸入されたもので, 飼 主の話によると，2才の頃米国に和いて狩猟訓練中に散 弾銃のタマを数発後頭部にうけ，その摘出手術をうけた 経歴をもち，しかも散弾をうけた部位と腫瘍発生部位が 一致している. しかし解剖の結果も頭蓋骨の内外側とも 全く異常がなく，かつ脳実質や脳膜にも異常がなかった ことなどから考えて, 後頭部にうけた散弾のいずれかが 頭蓋骨に陥入し，貫通一歩前の欠損孔を形成し，その後 脳圧によってついに貫通孔が形成され，その部位から頭 蓋外の頭部皮下に脳硬膜の一部が突出したのち, 治癒閉 鎖し, 頭部皮下にとり残された脳硬膜が，時間の経過と
ともに腫瘍化が進行し,ついには小児頭大にまで増大し たものと考えられる.

〔本論文の概要は, 昭和 54 年度日本臨床獣医学会（東 京）に拈いて発表した.」

\section{文献}

1) Andrews, E. J.: J. Am. Vet. Med. Assoc., 163, $151 \sim 157$ (1973).

2) GeIb, L. W.: Pathol. Vet., 3, 247 254 (1966).

3) Langham, R. F., et al.: J. Am. Vet. Med. Assoc., 159, 175 176 (1971).

4) Lawrence, A. N.: J. Am. Vet. Med. Assoc., $174,1224 \sim 1227$ (1979).

5) Luginbuhl, H.: Am. J. Vet. Res., 22, 1030 1040 (1969).

6）管野晴夫, 小林 博：腫瘍病理学, 初版, 824 870, 東京, 朝倉書店 (1970).

7) Magrane, W. G.: J. Small Anim. Pract., 6, 165 169 (1965).

8) Moulton, J. E.: Tumors in Domestic Animals, 208〜210 (1961).

9）鈴江 懐, 小林忠義 : 病理学各論, 初版, 1277 1279, 東京, 医学書院 (1967).

10)田中延吉, ほか：日獣会誌, 21 (臨), 582 (1968).

11) 富村 保, ほか：日獣会誌, 21 (臨), 583 (1968),

\title{
動物用ワクチンの概要とその正しい使い方 (XIX)
}

\section{1. 馬鼻肺炎ワクチン}

$$
\text { 倉 田 一 明* }
$$

\section{1. 馬鼻肺炎の現状と予防注射}

馬鼻肺炎はウイルス性の疾病で，子馬の初感染では発 熱, 鼻漏を主徵とする鼻肺炎，妊娠中期以降の感染馬で は, 胎子感染の結果, 死流産や, 生後間もなく死亡する ものが認められる.

同一のウイルスでありながら，馬に発現する症状が異 なることから, 一時, それぞれの症状は, 別個のウイル スによるものと考兄られた. しかし, 研究の結果, これ らの原因ウイルスは, 病原性や抗原性などの点で区別で きないことが判明した。

当初, 本病の原因ウイルスは馬流産ウイルスの名称で

* 農林水産省動物医薬品検査所（東京都国分寺市戸倉 1-15-1)
呼ばれたが，馬の流産は他のウイルスによっても起きる ため, この名称が不適当となり, ウイルス固有の親和性 臓器にもとずいて, 馬鼻肺炎ウイルスの名称が提唱さ れ，使用されている。

このウイルスは, Herpes 科の馬 Herpes ウイルス 1 型に属し，2つの亜型がある. 1つはアメリカで初めて 検出され, 死流産を主徵とする亜型 1 (アメリカ型)で, 亜型2 (日本在来型) は, わが国の馬の間に流行して拉 り, 主として呼吸器症状を起こすが, 時には死流産もみ られる. 両者の間には一部共通抗原が認められ，中和反 応で区別できるが，CF反応では区別できない，また， アメリカ型は馬赤血球を凝集するが，日本在来型には認 められない.

馬 Herpes ウイルスには, 他に, 2 型として馬サイト

日獣会誌 $34 \quad 387 \sim 390 \quad$ （1981） 
技

メガロウイルス， 3 型として馬婧疹ウイルスがあり，わ が国の馬の間にも存在しているといわれているが，馬鼻 肺炎ウイルスとの間には, 中和試験で抗原的関係は認め られていない。

ウイルス粒子は直径 100 130 nm の球型で, 構成核 酸はDNAである. 血清を含むメジウムでー $70^{\circ} \mathrm{C}$ 以下に 保存すれば, 感染性は安定であり, 紫外線, 熱, 脂質溶 剤やホルマリンで不活化される.

本ウイルスは, 八ムスターに馿化されたものるある が, 馬以外の動物の感染は認められていない. 培養細胞 では, 馬, 牛, 山羊, 豚, 家鬼などの腎でよく増殖し, それぞれC P Eを示す．このほか，各種哺乳動物の細胞 系でもよく殖える.

本症には初感染と両感染があり, 子馬は離乳後, 日本 在来型またはアメリカ型の初感染を受けて鼻肺炎を示 し, その後, 両感染した場合, 娃娠中期以降の馬では死 流産が起きる.

潜伏期は 13〜30 日位で, 前駆症状はなく, 突然発症 する. 鼻肺炎を主徵とする感染は, 生産地で離乳直後の 子馬や，集団飼育に入った馬に集団的に発生する．結膜 炎, 発咳, $39.0 \sim 41.5^{\circ} \mathrm{C}$ の一過性の発熱, 水様または膿 様の鼻漏, 靧下リンパ節の腫大, 元気, 食欲の減退等が みられる. しかし, 細菌の二次感染を起こすと経過が長 びく. 妊娠中期以降の馬が感染すると, なんら前兆なく 死流産を起こしたり，生後間もなく死亡するものも認め られ, 死流産は, 妊娠 8 11 カ月の感染馬に高率に出現 する.

診断には, ウイルス学的あるいは血清学的試験が行な われるが, ウイルス学的試験による方が迅速, 確実であ る.

鼻肺炎の症例については, 発症時の箅汁を採取し, 流 産の場合には, 胎子の肺, 腎, 肝, 脾等の乳剂につい て, ウイルスの分離を行なう. その際, 使用する培養細 胞としては, 馬腎細胞が最も感受性が高く, $2 \sim 3$ 日後 にC P Eが出現する.また，試料を接種した培養細胞 や, 流産胎子の臟器塗抹について, 螢光抗体法を実施す ると, 細胞核内に特異螢光が認められる. 感染細胞を $\mathrm{HE}$ 染色すると，核内封入体を検出できる.

血清学的試験では, 発病時と回復時の血清について, C F , H I あるいは中和反応を行ない, 抗体価を比較し て有意の上昇があったか否かにより診断される．死流産 を呈した場合には, 感染後, 少なくとも 10 日以上を経過 していることから，母馬には高い抗体価が認められる.

子馬は，ほとんど 9 月末から 11 月にかけて離乳し， 集団飼育されるが, 晚秋から初冬にかけて鼻肺炎の初感 染を受ける.この時, 鼻汁中には約 2 週間以上にわたっ て多量のウイルスを含有して拈り, 直接鼻汁を介したり, 人や污染した器物, 飼料を介して間接的にも伝播する.
講

座

この時期に, 妊娠中期以降の馬が感染すると，12月末頃 から死流産が発生し， $2 \sim 3$ 月頃に多発する. 流産胎子 には多量のウイルスが含まれ，これが伝播源となって， $4 〜 6$ 月頃には前年感染を受けなかった馬に鼻肺炎がみ られる.

1933年に，アメリカで初めて報告された本症は，今で は，ほぼ全世界に蔓延している，わが国では，1957 年 に, 馬流産胎子の肺, あるいは鼻肺炎を呈した馬の鼻汁 から本ウイルス（日本在来型）が分離され, 初めて本症 の存在が確認された. 1966年頃から輸入馬が増加する傾 向がみられ，1967年春, 北海道および千葉県で輸入馬を 中心に死流産が多発し, 流産胎子から, わが国ではかつ てみられなかった抗原型のウイルス（アメリカ型）が分 離され，大きな被害と恐怖を与えた，その後も，この型 のウイルスによる死流産が北海道の一地方を中心に散発 的に発生し, その後も每年発生が続き, 現在では, 日本 在来型とともに, この型のウイルスもほぼ定着した状態 である.

死流産を予防するため, 当初, アメリカ製の生ワクチ ンについても，妊娠馬を用いて実験的な検討が行なわれ たが，ウイルスの病原性がな抬く、ワクチンによる危 険性が考兄られ，実用に至らなかった。安全, 有効なワ クチンの開発を目指し, 家畜衛生試験場を中心に研究が 続けられた結果, 濃縮不活化ワクチンの量産に成功し, すでに 1979 年から使用されている.

\section{2. 馬鼻肺炎ワクチンの概要}

わが国のほとんどの馬は，すでに日本在来型ウイルス の感染を経験していることから, 死流産の予防を主目的 に, アメリカ型ウイルスによる不活化ワクチンの開発が 進められてきた。

このワクチンの製造用ウイルスには，1967年，わが国 の感染馬の流産胎子から分離された $\mathrm{HH}-1$ 株が用いら れている. 分離後, 馬腎と牛腎培養細胞で継代, 馴化 後, 子牛腎株化 CKTC 6-1 細胞によるウイルス培羑法 を確立し，大量培養への準備が整兄られた．CKTC 6-1 細胞は浮遊培養法で增殖するので，大型タンクを用いて ウイルスの量産が可能となり, ワクチン製造に成功し た.わが国で, 動物用ワクチンの製造に, 浮遊培養法が 用いられたのは，本ワクチンが最初である.

ワクチンは, ウイルス培養後約 30 時間目に培盖液を 集め, 遠心により上清を採取し，マクロゴールの添加と 超音波処理により，ウイルスの濃縮と部分精製を行な い, ホルマリンを $0.2 \%$ の割合に添加して不活化後, リ ン酸アルミニウムゲルを加えたるのである.

ワクチンは, 製造所比打る自家検查が終了後, 都道 府県の薬事監視員により, 規定量を無作為にサンプリン グされ，国家検定を受けるため，当所湜出される. 
技

術

国家検定は基準に従って，(1)特性，(2)純粋，(3)無菌， (4)防腐剂定量, (5)蛋白窒素含有量, (6)不活化, (7)安全特 よび(8)力価試験が行なわれる.

(1)〜(5)については，他のワクチンの場合と同様に実施 されるが，(5)では，試験品の蛋白窒素含有量は $0.5 \mathrm{mg} / \mathrm{ml}$ 以下に規定されている. (6)は，製造の過程で，ウイルス 不活化の処理が終了し，アジュバントを添加する前に試 料を採取することが定められており，その試料 $5 \mathrm{ml}$ 以 上を 100 倍量以上のリン酸緩衝食塩液 ( $\mathrm{pH} 7.4$ ) を用い て, $4{ }^{\circ} \mathrm{C} て ゙ 1$ 夜透析し, 不活化剂を除去したものを試験 材料とする. その全量を, $1 \mathrm{ml}$ につき $3 \mathrm{~cm}^{2}$ 以上の培 養牛腎株化MD B K 細胞に接種し， $37^{\circ} \mathrm{C} て ゙ 7$ 日間培養， 観察し，CPEを認めてはならない. (7)は，約 4 週齢の マウス 5 匹と, 体重約 $300 \mathrm{~g}$ のモルモット2 匹を用い, 試験品をマウスには $0.5 \mathrm{~m} l$ ずつ腹側皮下に, モルモット には $2 \mathrm{~m} l$ を両臀部の筋肉内に注射して 14 日間観察し, 注射部位に軽度の腫脹, 硬結を認めることがあっても, 試験終了時には全く異常を認めてはならない.88は, 約 6 週齿のハムスター 20 匹を用い, 試験品をリン酸緩衝 食塩液で 250 倍から 2,000 倍まで 2 倍階段希釈し，各希 䣋について 4 匹のハムスターに, 希橎した試験品 $1 \mathrm{~m} l$ ずつを腹腔内に注射する. その後 3 週目に, 対照のハム スター 4 匹とともに，八ムスターに病原性を示す $\mathrm{KyD}$ 株ウイルスを腹腔内注射し，7 日間観察する. その結果， 試験品を注射した群の $50 \%$ 感染防御価は 500 倍以上で, 対照群はすべて死亡しなければならない.

試験品は, 以上の 8 種類のすべての試験に合格したと き，国家検定合格と判定され，合格証紙を貼布されて市 販される.

ワクチンは, $5 \mathrm{ml}$ 容量のバイアルに $5 \mathrm{ml}$ ずつ分注, 密栓されて和り，2〜 $5^{\circ} \mathrm{C}$ の冷暗所に保存すれば, 国家検 定合格の䍿日から 1 年間有効である.

\section{3. 使 用 法}

使用に先立って，ワクチンに添付されている使用説明
講座

書を熟読し，指示されている以外の方法で使用すること は適当でない。

ワクチンは乳白色の不透明な液体で，沈殿状をして稿 り, 十分に振璗し, 内容を均一にしてから使用すること が大切である.

用法, 用量は, 妊娠 $6 \sim 7$ カ月の馬の筋肉内に, $5 \mathrm{ml}$ を 4 週間隔で 2 回注射するよう定められている.

本ワクチンの安全性と有効性については, 実験小動物 以外に，馬を用いた実験室内試験や野外試験で確認され ている. 時として, ワクチン $0.5 \mathrm{ml}$ を腹側皮下に注射 されたマウスや，ワクチン $10 \mathrm{ml}$ (2 倍量) を 2 回筋肉 注射された馬の僅少例に, 注射部位に軽度の腫脹が認め られることもあるが, 数日内に消失する.

ワクチンが宿主にもたらす免疫を増強するために, 色 々な種類のアジュバントが研究されて拉り, 本ワクチン には,アジュバントとしてリン酸アルミニウムゲルが添 加されている. 上述の注射部位にみられる反応は, アジ ユバントに起因するものと考えられる.

日本在来型とアメリカ型ウイルスの間に, 一部共通抗 原性の認められること, 本ワクチン製造用ウイルスとし て，アメリカ型のウイルスが使用されていたことはす でに述べた. 日本在来型の感染を経験した馬では, アメ リカ型の感染を完全に阻止できないが，日本在来型の抗 体を保有する馬に，アメリカ型の不活化ワクチンを注射 すると，両方の免疫が得られることが知られて特り，本 ワクチンの効果が期待される.

現在，わが国ではこの不活化ワクチンだけが使用され ているが，国によっては生ワクチンも使用されており， 完全に本病から馬を守るためには, 今後, 安全な生ワク チンの開発も望まれる. 本症の原因ウイルスが Herpes 科のウイルスであることから，このウイルス特有の感染 形態, 持続性潜伏感染と再発の問題についても, さらに 研究を進める必要があるら。

\section{2. 馬ゲタウイルス感染症ワクチン}

\section{1. 馬ゲタウイルス感染症の現状と予防注射}

1978 年 9 月末から 11 月初旬にかけて, 関東地方の競 走馬トレーニングセンターや育成牧場の馬に, 発熱, 発 疹および下肢の浮腫を主徵とする疾病が流行した。 その 流行はあまり激しくなく, 除々に厩舎に蔓延し, 初発後 約 2 カ月で終息した.

このような馬の疾病はわが国では経験がなく，色々な 角度から研究された結果, ゲタ (Getah) ウイルスによ

\section{る疾病であることが判明した。}

ゲタウイルスは, Togavirus 科の Alphavirus 属（従 来の arbovirus のうち，A群ウイルスの大部分が包含さ れている）に所属し，蚊によって人，家畜，野性の温血 動物に伝播されることが知られている. 本ウイルスは直 径約 $70 \mathrm{~nm}$ の球型で，構成核酸はR NAである. 脂質 溶剤で失活し，硫酸プロタミン処理で沈降せず，デゾキ シコール酸処理で感染価が失なわれ，トリプシンには低 抗性で，ガ鳥赤血球を凝集（至適 $\mathrm{pH}$ 6.0 6.4）する. 
技

術

また，かなり広範囲の動物（猿，馬，豚，ハムスター,人 等) 由来の培養細胞でC P Eを伴って增殖し, 乳飲みマ ウスに強い病原性を示す. 1978年の流行時に打けるウイ ルス分離は，発症馬からの血液や鼻腔ぬぐい液を, Vero 細胞や乳领みマウスに接種して行なわれた。 また， HI， CF 拈よび中和反応が血清学的試験に用いられるが, 中 和反応は本ウイルスの同定に役立つ.

ソ連, マレーシア，オーストラリア，わが国等で， 馬, 牛, 豚, 鳥類, 山羊等飞, H I あるいは中和抗体が 検出されている，わが国では，1956年にサギヤマウイル ス，1959年にイタクラウイルス，1965年にハルナウイル スの株名で,ゲタウイルスが蚊あるい性から分離され, 1965 年には大阪府下の蚊からも分離されている。 しか し，これらウイルスによる動物側の症状は明らかにされ ていない.

馬の症状は一般に軽く, $38.5 \sim 41.0^{\circ} \mathrm{C}$ の発熱が数日続 き, 一部には, 米粒大〜小豆大の発疹が注注全身に発現 したり，下肢に浮腫を呈する例もみられる．発咳や鼻漏 は認められず, 元気, 食欲に著変なく, 回復には約 1 週 間を要する。

ゲタウイルスの自然界に扣ける伝播は，従来から，日 本脳炎の場合と近似し，ウイルス保有動物を吸血して感 染した蚊（節足動物）は，体内でウイルスを増殖させ， 他の動物を吸血する際に，その動物にウイルスを伝播す ると考兄られている. しかし, 馬の場合, ウイルス伝播 の方法は明らかでない。

本病の予防対策として, ワクチンの開発が望まれてい たが，1981年，不活化ワクチンの製造が許可された.

\section{2. ゲタウイルス感染症ワクチンの概要}

1978 年の流行時に, 発症馬から分離された M I - 110 株が，ワクチン製造用ウイルスとして使用されている.

ワクチンは, ウイルスを馬胎子由来の皮膚株化細胞で培 養し, ウイルス增殖の極期に培養液を採り, マクロゴー ルを添加してウイルスの濃縮, 部分精製を行ない, ホル マリンで不活化したものである.

製造されたワクチンは自家検査終了後, 薬事監視員に よりサンプリングされ, 当所湜出されて国家検定を受 ける。

国家検定は基準飞従い，(1)特性，(2)純粋，(3)無菌，(4) 防腐剤定量, (5)蛋白窒素含量, (6)不活化, (7)安全および 力価試験が行なわれる.

(1)〜(5)については，他のワクチンの場合と同様に実施 されるが, (5)では, 試験品の蛋白窒素含有量が $0.2 \mathrm{mg} /$ $\mathrm{m} l$ 以下に規定されている. (6) は, 試験品を透析して不 活化剂を除き，その $2 \mathrm{ml}$ 以上を, $1 \mathrm{ml}$ につき $3 \mathrm{~cm}^{2}$ 以上の培養 Vero 細胞飞接種する. $37^{\circ} \mathrm{C} て ゙ ~ 10$ 日間培 養, 観察し，CPEの出現を認めず，10日目の培養液は
講㭫

ガ鳥赤血球を凝集してはならない（7)は，約 4 週龄のマ ウス 5 匹と, 体重約 $300 \mathrm{~g}$ のモルモット 2 匹を用い, 試 験品をマウスには $0.5 \mathrm{ml}$ ずつ皮下に, モルモットには 5 $\mathrm{m} l$ ずつ腹腔内に注射して 10 日間観察し, 異常を認めて はならない.8は, 約 6 週齢のハムスター12匹を用い, 試験品を $1 \mathrm{~m} l$ ずつ 10 匹の皮下に注射し， 2 匹を対照 とする. 注射後 21 日目にすべてのハムスターから採血 し, ワクチン注射群と対照群の, それぞれ 2 匹ずつ等量 混和した血清を試料とする. 各試料を 2 倍階段希釈し， 約 $200 \mathrm{TCID}_{50}$ のウイルスと混和し, 培養 Vero 細胞に 接種して 7 日間培養, 観察し, 中和抗体価を測定する. 中和抗体価 2 倍以上を陽性とし, 注射群の $80 \%$ 以上が 陽性であり, 対照群は陰性でなければならない。

試験品は, 以上の 8 種類のすべての試験に合格したと き, 国家検定合格と判定される.

ワクチンは, $5 \mathrm{~m} l$ 容量のバイアルに $4 \mathrm{ml}$ ずつ, また は, $10 \mathrm{~m} l$ 容量のバイアルに $10 \mathrm{~m} l$ ずつ分注されてい る. $2 \sim 5{ }^{\circ} \mathrm{C}$ の冷暗所に保存すれば，国家検定合格の翌 日から 1 年間有効である.

\section{3. 使用法}

このワクチンの用法, 用量は, 初回免疫の場合, $2 \mathrm{~m} l$ を 4 週間隔で 2 回, 補強免疫には $2 \mathrm{~m} l$ を年 1 回, 馬の 頸側部筋肉内に注射するように定められている.

わが国において，ゲタウイルスはすでに蚊または豚か ら検出され，今回，馬から分離されたが，自然界に和け るウイルス伝播のパターンはそれ程明らかにされていな い. 1978 年と 1979 年の馬飞批ける流行の結果, 流行の ピークは関西では 7 月下旬から 8 月上旬, 関東では 9 月 中旬から11月下旬にみられ，流行に地域差があることが 窥われる. したがって, 予防注射の時期は, 現状では, 過去の経験と最近の情報に基づいて計画をたてるのが良 策であろう.

本ワクチンの注射により，抗体陰性の馬では，2 回目 の注射後約 1 週目から中和抗体の上昇が認められ, 約 4 カ月間持続することが報告されている.

ゲタウイルスの伝播に関する今までの報告や, 感染馬 浔められたウイルス血症等から, 本ウイルスは蚊（節 足動物）によって馬から馬へ伝播することが考兄られ， 他の家育からも抗体が検出されていることから, 今後, 馬はもちろん, 他の家畜の感染についても, 十分注意を はらら必要がある。

また，わが国に和ける馬の流行で, 蚊の活動時期と無 関係のような流行があったり, 感染馬の鼻腔妨ぐ液に かなり多量のウイルスが含有されていること等から，蚊 （節足動物）以外のウイルス伝播様式についての検討も, 今後の課題であろう。 